\title{
Benefits from using recycling red blood cells in cardiovascular surgery
}

\author{
R Almeida*, M Steinbach, M Centenaro \\ From 23rd World Congress of the World Society of Cardio-Thoracic Surgeons \\ Split, Croatia. 12-15 September 2013
}

\section{Background}

Due to problems related to blood transfusion, decision by patients and the shortness of blood stocks, cardiovascular surgery is finding new paths, for not using homologous blood supplies. The authors will show if blood salvage (BS) is indicated in all patients submitted to cardiovascular surgery.

\section{Methods}

We studied 77 consecutive patients submitted to cardiac surgery with use of BS and extra-corporeal circulation (ECC) from November 2010 to June 2012. All cases, except redos, were included and performed by only one surgeon. The sample was divided in three groups, depending on the time of ECC. In group A, the time of ECC was smaller than 45, in group B from 45 to 90 and in group $C$ greater than 90 minutes. We analyzed the volume of red cells recovered and infused, the pre, intra and post-operative hemoglobin $(\mathrm{Hb})$ and the number of packed red cells (PRC) units, which were transfused. The parameters to blood transfusion were $\mathrm{Hb}$ lesser than 8,0 or $9,0 \mathrm{~g} / \mathrm{dl}$ whether the patient was hemodynamically unstable.

\section{Results}

The average group' age was $60,44 \pm 12,09$ years old, of whom $71,43 \%$ were males. The group A was formed by $5,19 \%$ of the patients, B by $81,82 \%$ and C by $12,99 \%$. The volume of erythrocytes recovered and infused was respectively $1.360,50 \pm 511,37 \mathrm{ml}$ and $339,75 \pm 87,71 \mathrm{ml}$ in group A, 1.436,63 $\pm 516,06 \mathrm{ml}$ and $518,83 \pm 183,0 \mathrm{ml}$ in $B$ and $2.137,00 \pm 925,04 \mathrm{ml}$ and $526,20 \pm 227,15 \mathrm{ml}$ in C. About PRC transfusions, in group A $1,00 \pm 2,00$ PRC were transfused, in $\mathrm{B} 1,27 \pm 1,85 \mathrm{PRC}$ and in $\mathrm{C}$ $2,56 \pm 2,01$ PRC.

\footnotetext{
* Correspondence: ruimsalmeida@iccop.com.br Cardiovascular Surgery, FAG, Cascavel, Brazil
}

\section{Conclusions}

That BS can be used in all patients submitted to cardiovascular surgery with ECC. However, it is only costeffective in surgeries whose time of ECC is greater than 45 minutes.

Published: 11 September 2013

doi:10.1186/1749-8090-8-S1-0160

Cite this article as: Almeida et al:: Benefits from using recycling red blood cells in cardiovascular surgery. Journal of Cardiothoracic Surgery 2013 8(Suppl 1):0160.
Submit your next manuscript to BioMed Central and take full advantage of:

- Convenient online submission

- Thorough peer review

- No space constraints or color figure charges

- Immediate publication on acceptance

- Inclusion in PubMed, CAS, Scopus and Google Scholar

- Research which is freely available for redistribution

\section{Biomed Central}

